\title{
FUNDACJE ARTYSTYCZNE KSIĘŻNICZKI BAWARSKIEJ MARII KLARY WITTELSBACH, W ZAKONIE SIOSTRY TERESY MARII OD ŚW. JÓZEFA (1608-1652), KARMELITANKI BOSEJ W KRAKOWSKIM KLASZTORZE ŚW. MARCINA
}

Osoba zapowiedzianej w tytule krakowskiej zakonnicy jest znana badaczom dziejów najstarszegō polskiego konwentu karmelitanek, osadzonych w 1612 roku przy gotyckim kościele św. Marcina w Krakowie. W swoim monumentalnym opracowaniu historii zakonu karmelitańskiego w Polsce Ojciec profesor Józef Benignus Wanat specjalnie podkreślił fakt, iż wczesnobarokowa świątynia klasztorna karmelitanek, zbudowana przy ul. Grodzkiej w latach 1638-1641 (poświęcona w 1644 roku), powstała dzięki hojnemu zapisowi właśnie s. Teresy Marii od św. Józefa'. Życiorys s. Teresy został opracowany przez o. Czesława Gila w jego zbiorze biogramów karmelitanek bosych ${ }^{2}$, a ostatnio jej osobę wzmiankowała Ka-

${ }^{1}$ Zob. B. J. W a n a t, Zakon karmelitów bosych w Polsce. Klasztory karmelitów i karmelitanek bosych 1605-1975, Kraków 1979, s. 626. Informację o legacie na kościół (w wysokości 10 tysięcy złotych) złożonym przez s. Teresę Marię od św. Józefa podaje jednoznacznie cenne, a słabo dotychczas wykorzystane źródło, jakim jest rodzaj chronologicznego zestawienia najważniejszych wydarzeń w dziejach klasztoru św. Marcina, na które złożyły się wyciagi z zachowanej kroniki konwentu (zob. następne przypisy) oraz - co bardzo cenne - z niezachowanych rachunków i innych zapisek; zob. Archiwum Klasztoru Karmelitanek Bosych na Wesołej w Krakowie (dalej AKKB), rkps sygn. 38 (Księga czynszów konwentu św. Marcina napisana w $R$. P. 1756, zaczynajaca się od roku 1753), k. 262-268 (wyciąg ten, pisany dwoma rękami, osobno za lata 1612-1754 - ten fragment spisany zapewne ok. $1775 \mathrm{r}$. oraz osobno za lata 1754-1787 - tych uzupełnień dokonano najprawdopdobniej ok. 1827 r.; dalej cyt. jako AKKB, rkps sygn. 38, Księga...), s. 265. Na temat kościoła św. Marcina zob. m.in. M. B ryk ow s k a, Architektura karmelitów bosych w XVII-XVIII wieku, [w:] Studia i Materiały do Teorii i Historii Architektury $i$ Urbanistyki XVIII, Warszawa 1991, s. 89 i in. (według indeksu); tu dalsza literatura przedmiotu. por. też niepublikowaną rozprawę A. Kluczewskiej, Kościól św. Marcina w Krakowie, praca magisterska napisana pod kierunkiem prof. dr. hab. Adama Małkiewicza w Instytucie Historii Sztuki Uniwersytetu Jagiellońskiego w Krakowie, Kraków 1987, mps m.in. w Bibliotece Klasztoru Karmelitanek Bosych na Wesołej w Krakowie.

${ }^{2}$ C. G il, Slownik polskich karmelitanek bosych 1612-1914, Kraków 1999, s. 31-32, tamże zebrane w komplecie źródła i literatura przedmiotu. 
rolina Targosz ${ }^{3} \mathrm{i}-$ nie po raz pierwszy - s. Małgorzata Borkowska ${ }^{4}$, a także nieco obszerniej omówil autor niniejszego komunikatu, rozpatrując jej fundacje artystyczne w kontekście dziejów relacji artystycznych Krakowa z Augsburgiem w XVII wieku ${ }^{5}$. W dalszym ciagu jednak osoba bawarskiej księżniczki zasługuje na zainteresowanie badaczy: historyków zakonu karmelitańskiego i historyków sztuki. Właśnie możliwość omówienia jej wkładu w skompletowanie wystroju klasztornej świątyni karmelitanek, z obszerniejszym niż dotychczas wykorzystaniem źródeł, skłania autora do ponownego podjęcia tematu fundacji s. Teresy dla kościoła św. Marcina w Krakowie.

Siostra Teresa Maria od św. Józefa - przed wstapieniem do zakonu Maria Klara Wittelsbach - urodzona 10 marca 1608 roku, była najmłodszą z licznego potomstwa księcia Ferdynanda Wittelsbacha (1550-1608) i Marii (1574-1614), córki Jerzego von Pettebeck. Jej ojciec był młodszym bratem panującego w Monachium Wilhelma V (1548-1626) i zarazem starszym bratem Marii (1551-1608), żony arcyksięcia Karola Habsburga (1540-1590), brata i stryja cesarzy Maksymiliana II i Rudolfa II. Dwie córki arcyksięcia Karola i Marii (ciotki naszej bohaterki): Anna (1573-1598) oraz Konstancja (1588-1631) były kolejno żonami króla Zygmunta III Wazy ${ }^{6}$. To bliskie pokrewieństwo thumaczy, dlaczego wcześnie osierocona Maria Klara Wittelsbach wychowywala się od 1618 roku na dworze swojej kuzynki, królowej Konstancji w Warszawie. Przebywając w Krakowie w 1633 roku, z okazji pogrzebu Zygmunta III i koronacji Władysława IV, poznała karmelitanki bose i rychło zdecydowała się wstapić do klasztoru św. Marcina w Krakowie. Habit zakonny otrzymała 21 lutego 1634 roku w obecności rodziny królewskiej (w tym królewny Anny Katarzyny Konstancji i królewicza Jana Kazimierza), a więc faktycznie najbliższych krewnych Marii Klary, a po pełnym surowych prób nowicjacie, 21 lutego 1635 roku, złożyła profesję zakonna. Mimo swojego bardzo wysokiego pochodzenia traktowana była na równi z innymi siostrami, a źródła klasztorne przytaczają niezmiernie charakterystyczną anegdotę świadcząca o tym fakcie: gdy przechodząca pewien kryzys w ćwiczeniu swojej pokory bawarska księżniczka usiłowała „szantażować” swoją mistrzynię (Annę od Jezusa - Jadwigę Stobieńską) możliwością opuszczenia klasztoru, usłyszała jedynie "Tędy do drzwi" ". Wydarzenie to na stałe weszło do karmelitańskiej tradycji.

Maria Klara Wittelsbach - s. Teresa Maria od św. Józefa okazała się znakomitym ,nabytkiem" dla krakowskiego konwentu, nie tylko ze względu na wniesiony majątek i swoje doskonałe kontakty $\mathrm{z}$ dworem królewskim, ale przede

${ }^{3}$ K. Targosz, Piórem zakonnicy. Kronikarki w Polsce XVII w. o swoich zakonach i swoich czasach, Kraków 20022 , s. 143. Tu, a takze w następnych przypısach, uwzględnıam jedynie te publikacje, które ukazały się po wydaniu cytowanego słownika o. Gila.

${ }^{4}$ M. B or k ow s k a, Panny siostry w świecie sarmackim, Warszawa 2002, s. 18.

${ }^{5} \mathrm{~J} . \mathrm{Z} \mathrm{m}$ u d z i ń s k i, Relacje artystyczne Krakowa z Augsburgiem $w$ dziedzinie złotnictwa w XVII w. Zarys problematyki badawczej, „Rocznik Biblioteki Naukowej PAU i PAN w Krakowie", R. XLVIII, 2001, s. 72-75.

${ }^{6}$ Sieć wzajemnego pokrewieństwa między Wittelsbachami, Habsburgami i Wazami pokazuje najlepiej W. D w o r z a c ze k, Genealogia. Tablice, Warszawa 1959, tabl. 75 (Wittelsbachowie - ksiązęta bawarsy na Monachium, bez uwzględniania potomstwa Ferdynanda Wittelsbacha i Marii, które znane jest pod nazwiskiem hrabiów Wartenberg) oraz tabl. 48 (Cesarze rzymscy z domu Habsburgów).

${ }^{7}$ B o r k ow s k a, Panny siostry..., dz. cyt. 
wszystkim ze względu na walory duchowe i zdolności organizacyjne. Wiadomo też, iż posiadała pewne umiejętności plastyczne ${ }^{8}$ oraz - w miarę ograniczeń wynikających z przynależności do zakonu - gromadziła dzieła sztuki, a konkretnie portrety rodzinne? ${ }^{9}$ Przebywała w Krakowie i przejściowo we Lwowie, a w 1649 roku została w swoim macierzystym klasztorze przeoryszą. Zmarła 12 listopada 1652 roku w Kielcach, w czasie gdy wraz $\mathrm{z}$ podległymi jej siostrami $\mathrm{z}$ powodu epidemii korzystała z gościny biskupa krakowskiego Piotra Gembickiego. Jej ciało sprowadzono do Krakowa i pochowano w kościele św. Marcina.

Źródła zakonne ${ }^{10}$ wystawiają jej bardzo dobrą opinię, niezależnie od tego podkreślona jest hojność bawarskiej księżniczki w stosunku do klasztoru, do którego zamierzała wstapić. Jak informuje prowadzona w latach 1612-1710, opublikowana w 1904 roku kronika konwentu św. Marcina, Maria Klara von Wittelsbach ,przed Profesyą sporządziła dobra swoje, oddają wszystko co miała klasztorowi, acz już była wiele rozdała pierwej niż weszła do klasztoru różnym osobom, jako to szaty i wiele rozmaitych i kosztownych sprzęcików i klejnotów, których było [za] około trzydziestu tysięcy. Dała na prowizyę roczną 26 tysięcy, na kościół odkazała dziesięć tysięcy, na srebro kościelne, które naumyślnie w Ausburgu robiono, to jest sześć lichtarzy, kielichów dwa, krzyż, lampa, trybularz, 5 tysięcy. Cymborya chebanowa [sic!], wewnątrz $z$ blachy a $z$ wierzchu posagi srebrne mająca - półczwarta tysiąca. Srebro, złoto, co drobniejsze i szaty na zakrystyą, za ostatki srebra, co drobniejszego sprzedawszy, półtora tysiąca na aparat altebaszowy"'1. Powyższe informacje w pełni potwierdzają inne, niepublikowane źródła klasztorne, w których pojawia się ta sama informacja - o zamówieniu w Augsburgu licznych sreber kościelnych oraz, jak można przypuszczać z brzmienia tych zapisów, także srebrnego wystroju tabernakulum (cyborium). Sporządzone w drugiej połowie XVIII wieku zestawienie najważniejszych wydarzeń z dziejów klasztoru św. Marcina, relacjonując bogatą fundację Marii Klary von Wittelsbach, podaje przy okazji informacje na temat dalszych losów augsburskich wyrobów złotniczych - pod data 1635 odnotowano tu wydatki z funduszy wniesionych przez księżniczkę bawarską (nie licząc 10 tysięcy złotych przeznaczonych na budowę nowego kościoła): „Na srebro kościelne, które umyślnie w Auszpurgu robiono 5000, to iest: lichtarzów sześć, kielichów dwa, lampa wielka z essami, to Szwedzi zabrali, krzyż wielki, thurybularz. Cyborium hebanowe wewnątrz blachy, zwierzchu posagi srebrne 3500 y to po części Szwedzi zabrali. Srebro złoto co drobniey-

${ }^{8}$ O. G i 1 (dz. cyt., s. 84) podaje, iż uczyła we Lwowie jedną z zakonnic robić figurki woskowe, sztuczne kwiaty i obrusy.

${ }_{9}$ Według kroniki klasztoru krakowskiego (Klasztory Karmelitanek Bosych w Polsce, na Litwie i Rusi, Kraków I. Klasztor św. Marcina, Kraków 1904 [opr. J. Kalinowski - św. Rafał Kalinowski], s. 102) s. Teresie Marii przysłano (niewatpliwie z Monachium) „obrazy wprawdzie małe, ale istotnie konterfekty Xiążęcia Bawarskiego ojca jej i matki i dwóch braci, jednego świeckiego a drugiego Biskupa i Siostry jej rodzonej, która była kiedyś w cudzych krajach zakonnica" (obraz te, zapewne miniatury, zrabowali Szwedzi w latach 1655-1657).

${ }^{10}$ Pośród nich naczelne miejsce zajmuje Żywot W. M. Teresy Maryey od Św. Józefa [w:] Xięgi w których sq krótko opisane żywoty zmarlych zakonniczek Bossych Zakonu Naświętszey Panny Maryi z Góry Carmelu w klasztorze krakowskim Ś. Marcina od Roku Pańskiego 1627, AKKB, rkps sygn. 253, s. 361-401.

${ }^{11}$ Klasztory.., dz. cyt., s. 44. 
sze y szaty na zakrystya, na aparat altembasowy 1500 "12. Wspomniany rabunek miał miejsce w czasie potopu szwedzkiego, gdy w latach 1655-1657 zakonnice opuściły klasztor św. Marcina, zamurowując najcenniejsze srebra w jednej z piwnic, skąd zrabowali je w końcu Szwedzi ${ }^{13}$. Wtedy to konwent utracił augsburskie wyroby złotnicze (wymienione srebra oltarzowe) z fundacji księżniczki bawarskiej Marii Klary.

Pozostało tabernakulum, które także zostało w czasie ,potopu” zubożone, a następnie uzupełnione nowymi ozdobami fundowanymi w miejsce utraconych ${ }^{14}$, ale aż do samego końca istnienia klasztoru przy kościele św. Marcina, czyli do kasaty w 1787 roku, stało na ołtarzu głównym i było dekorowane znaczną ilością srebrnych plakietek. Świadczy o tym bardzo szczególowy opis tabernakulum sporządzony niedługo przed opuszczeniem przez zakonnice klasztoru przy ul. Grodzkiej i przeniesieniem się do klasztoru na Wesołej (obecnie przy ul. Kopernika) ${ }^{15}$ zamieszczony w całości w Aneksie do niniejszego artykułu. Tabernakulum także przetransportowano na Wesoła, gdzie w 1793 roku odnotowano fakt sprzedaży srebrnej dekoracji z tego sprzętu ${ }^{16}$. Ostatecznie samo tabernakulum przetrwalo na ołtarzu głównym kościoła na Wesołej, gdzie opisane jest być może juź w 1793 ro$\mathrm{ku}^{17}$, a na pewno w 1819 roku, gdyż opis sporządzony w tym czasie wydaje się nie pozostawiać wattpliwości co do identyfikacji istniejącego do dziś tabernakulum ze sprzętem znanym z opisu kościoła św. Marcina sprzed 1787 roku $^{18}$. Niestety zniknął cały pierwotny wystrój cyborium zastapiony późniejszymi drobnymi elementami ze stopu miedzi i plakietą srebrną ze sceną Ukrzyżowania ${ }^{19}$, które należy da-

${ }^{12}$ AKKB, rkps sygn. 38, Ksiêga..., s. 265.

${ }^{13}$ Klasztory..., dz. cyt., s. 64, 65-66, 99-100.

${ }^{14}$ W 1667 roku sporządzono 24 gałki srebrne na cyborium, a w 1686 roku odnotowano wykonanie nowych figur srebrnych śś. Katarzyny i Cecylii oraz pary aniołów „co trzymaią Imie Jezus" przeznaczonych do ozdoby tabernakulum - wszystko to niewatpliwie w miejsce sreber zrabowanych przez Szwedów (por. AKKB, rkps sygn. 38, Ksiëga.., s. 266).

${ }^{15}$ AKKB, rkps sygn. 33, dokument luźny: Regestr srebra kościola S. Marcina, bez daty.

${ }^{16}$ AKKB, teczka 52, dokument luźny: Tax srebra tudzież pozwolenie konsystorskie sprzedania tegoż srebra, datowany 7 listopada 1793 roku. Te - jak głosi dokument - „niektóre ułomki srebra z ciborium kościoła Ś. Marcina" - zostały określone jako wykonane ze srebra próby 10 i ważyły 15 grzywien, 10 łutów i 3 - zapewne - skojce. Po ich stopieniu uzyskano srebro o wartości 626 złotych i 20 groszy.

${ }^{17}$ AKKB, rkps sygn. 33, dokument luźny: Regestr srebra y relikwiy znayduiacych się na ottarzach $w$ kościele naszym Karmelitanek Bosych na Wesoly spisane po wtóre w roku teraźniejszym $1793 \mathrm{cim}$; zamieszczony tu opis tabernakulum jest następujący: „w ołtarzu wielkim (...) cyborium całe hebanowe. Na wierzhcu tego cyfra w promieniach srebrna w środku tego Imię Jezus. Na drzwiczkach $z$ wierzchu w środku blacha srebrna $\mathrm{z}$ wyrazem Pana Jezusa Ukrzyżowanego, reszta w koło tej mosiężna posrebrzana, inne sztuczki na tym cyborium są mosiężne posrebrzane, i wszystkich jest w liczbie szesnaście. W cyborium jest dzbanuszków pięć z kwiatkami ale dzbanuszki srebrne, trochę pozłacane, małe".

${ }^{18}$ AKKB, rkps sygn. 33, dokument luźny: Regestr porzondków [sic!] wszelkich znayduiqcych się w kościele Karmelitanek Bosych na Wesoly przy Krakowie w roku 1819 dnia 29 października. Nie zajmuję się tutaj osobnym zagadnieniem dziejów i wyglądu tabernakulum, które musiało stać na ołtarzu w kościele na Wesołej przed ustawieniem tamże przeniesionego z ul. Grodzkiej i odartego ze srebrnej dekoracji tabernakulum fundacji Marii Klary Wittelsbach.

${ }^{19}$ Chciałbym w tym miejscu serdecznie podziękować Joannie Daranowskiej-Łukaszewskiej za pomoc w badaniu tabernakulum - na istnienie którego zwróciła moją uwagę - oraz por- 
tować najwcześniej na lata około 1793 roku. O istnieniu licznych dawnych ozdób świadczą czytelne na drewnianej strukturze sprzętu liczne otwory służące do mocowania srebrnej dekoracji.

W rezultacie więc do dziś w kościele karmelitanek przy ul. Kopernika w Krakowie pozostała pamiątka po hojnej fundacji księżniczki bawarskiej Marii Klary Wittelsbach $-\mathrm{s}$. Teresy Marii od św. Józefa. Musiała być to fundacja głośna jeszcze w XVII wieku, skoro Albrycht Radziwiłł wspomina pod rokiem 1647, iż szukając w czasie pobytu w Krakowie pretekstu do dyskretnego spotkania z kilkoma ówczesnymi osobistościami, wskazał na ten cel miejsce: „u mniszek karmelitanek, mianowicie pod pretekstem zobaczenia cyborium,"20. Wiadomość o fundacji augsburskich sreber do klasztoru św. Marcina, odnotowywana w literaturze ${ }^{21}$, uszła jednak uwadze badaczy złotnictwa w Polsce. Tymczasem jest to fakt bardzo interesujący, stanowi bowiem kolejny dowód bezpośrednich kontaktów dworu polskiego i środowiska krakowskiego z Augsburgiem. Tak więc, mimo iż karmelitańskie srebra ołtarzowe tam wykonane zaginęły już w XVII wieku, a tabernakulum zostało całkowicie pozbawione srebrnego wystroju, warto tym fundacjom poświęcić nieco uwagi.

Jeśli chodzi o tabernakulum, to problem jego artystycznego rodowodu należy traktować dwutorowo. Kwestią osobną jest kształt architektoniczny samego korpusu sprzętu. Zachowana do dziś drewniana struktura tabernakulum, określona w źródłach błędnie jako hebanowa, a w istocie sporządzona $\mathrm{z}$ pośledniejszego gatunku drewna, o powierzchni opracowanej w kolorze czarnym (przypuszczalnie za pomocą rodzaju politury), raczej na pewno powstała w jednym z miejscowych, krakowskich warsztatów stolarskich. Tabernakulum stojące dziś na ołtarzu głównym kościoła karmelitanek bosych przy ul. Kopernika posiada formę centralnej kopułowej świątyńki. Jej dolna partia wzniesiona jest na rzucie kwadratu o ściętych narożnikach. $Z$ przodu i $\mathrm{z}$ boków elewacje tabernakulum akcentują jońskie portyki wsparte na parach kolumn. W części gómej, powyżej ośmiobocznego tamburu opiętego półfilarkami widnieje niska kopułka zwieńczona latarnią. Całość do złudzenia przypomina projekt tabernakulum (czy właściwie niewielkiej świątyni centralnej), autorstwa rzymskiego architekta Giovanniego Battisty Montano (1534-1621), opublikowany w 1628 roku w zbiorze jego rysunków, pośmiertnie przygotowanych do druku przez Giovanniego Battistę Soria ${ }^{22}$. Jerzy Kowalczyk, który zajmował się ostatnio wpływem projektów Montano na sztukę polską, zwrócił uwagę na ten rysunek i wskazał na jego naśladownictwa w postaci małopolskich tabernakulów, m.in. w Rudawie koło Krakowa (aby pozostać przy dziełach

tretu fundatorki tego sprzętu, a także w poszukiwaniach archiwalnych prowadzonych w klasztorze karmelitanek przy ul. Kopernika.

${ }^{20}$ A. S. R a d z i w i H 1, Pamiętnik o dziejach w Polsce, t. 3: 1647-1656, przełożyli i oprac. A. Przyboś i R. Żelewski, Warszawa 1980, s. 51.

${ }_{21}$ Zob. np. S. Tomkowicz, Zabytki sztuki w klasztorze Karmelitanek na Wesolej w Krakowie, „Rocznik Krakowski”, t. XII: 1910, przypis 1 na s. 4; C. G i l, Zycie codzienne karmelitanek bosych w Polsce w XVII-XIX wieku, Kraków 1997, s. 56.

${ }^{22} \mathrm{~J}$. K ow al c z y k, Znaczenie wzorów Giovanniego Battisty Montano dla architektury barokowej w Polsce i na Litwie, „Biuletyn Historii Sztuki”, R. LXII, 2000, Nr 1-2, il. 12 na s. 18 oraz s. 31. 
z pierwszej połowy XVII wieku ${ }^{23}$ ). Warszawski uczony słusznie zauważył, iż w przywołanych przez niego polskich adaptacjach projektu Montano (których listę można by jeszcze poszerzyć ${ }^{24}$ ) zredukowano wieloboczny tambur, stanowiący ważny element koncepcji włoskiego architekta. W przypadku tabernakulum z kościoła św. Marcina tambur ten uwzględniono, co czyni podobieństwo do rysunku Montano tym bardziej uderzające. Nic nie stoi na przeszkodzie, aby - wziąwszy pod uwagę koneksje fundatorki - szukać autora projektu krakowskiego tabernakulum z około 1635 roku w kręgu architektów dworu królewskiego w Warszawie.

Do tak zakomponowanej architektonicznej struktury Maria Klara Wittelsbach zamówiła srebrny wystrój. $Z$ cytowanych wyżej źródeł zdaje się wynikać, iż podobnie jak komplet ołtarzowy, został on wykonany w Augsburgu, gdzie być może przesłano projekt tabernakulum. Znamy inne przykłady realizowania w Polsce niewielkich sprzętów kościelnych, sporządzanych z użyciem srebrnych ozdób produkcji augsburskiej. Tabernakulum do kościoła wizytek w Warszawie, fundacji królowej Marii Ludwiki, zostało wykonane tuż po 1654 roku z wykorzystaniem dekoracji, która wcześniej spoczywała w skarbcu Zamku Królewskiego w Warszawie $^{25}$. Z kolei analiza obecnie istniejącego tabernakulum warszawskiego, późniejszego o około 10 lat od pierwotnej fundacji królowej (zrabowanej w czasie „potopu” przez Szwedów), wyraźnie przekonuje, iż jego konstrukcja została wykonana na miejscu, w Warszawie, a same ozdoby srebrne sporządzono w Augsburgu na początku XVII stulecia ${ }^{26}$. Analogicznie (pominąwszy różnice w chronologii partii drewnianych i srebrnych) mogło być w przypadku fundacji Marii Klary Wittelsbach w kościele krakowskim. Pozostaje tylko żałować, iż jedynie z inwentarzowego opisu (zob. Aneks) znamy srebrny wystrój tego tabernakulum - owe sztuczki, droty w groszek, esiki, gałki, blaszki, wazoniki, gzemsiki, floresy, także plakiety i plakietki figuralne (na drzwiczkach z przedstawieniem trójosobowej sceny Ukrzyżowania; inne określone ogólnie jako obrazki w ramkach srebrnych),

${ }^{23}$ Kowalczyk (tamże, przypis 65 na s. 31) zwrócił uwagę na zbyt wczesne (przed 1617) datowanie tabernakulum w Rudawie, podane w Katalogu zabytków sztuki w Polsce (t. I, Wojewódtzwo krakowskie, pod red. J. Szablowskiego, Warszawa 1953, s. 124) - Kowalczyk sugeruje datowanie na drugą tercję XVII wieku, a Jan Samek, który publikował już wcześniej ten zabytek (zob. tenże, Malopolskie tabernakula z XVII wieku w ksztalcie centralnej, otwierajacej się światyni, „Teka Komisji Urbanistyki i Architektury”, t. XXV, 1992, s. 136, il. 4-5 na s. 137), datował go na połowę XVII wieku.

${ }^{24} \mathrm{~Np}$. o tabernakulum z kościoła parafialnego w Nowym Wiśniczu, datowane na czas przed 1630 rokiem (o zredukowanym - w stosunku do pierwowzoru Montano - tamburze) zob. P. S. S z l e z y n g e r, Kościót parafialany p.w. Wniebowzięcia Najświętszej Marii Panny w Nowym Wiśniczu, „Teka Komisji Urbanistyki i Architektury”, t. XXV, 1992, s. 155-156, il. 11 na s. $153-z$ pomylonym podpisem: zob. podpis na s. 156 , gdzie tabernakulum datowane na czas około 1620 roku.

${ }^{25}$ Zachowała się nawet relacja, w której wizytki opisuja, jak w czasie swego pobytu u królowej latem 1654 roku wprowadzono je do skarbca i pokazano części przyszłego tabernakulum: „po raz pierwszy pokazano nam wszystkie części naszego tabernakulum, z sześcioma kandelabrami i krzyżem, zanim zostały ustawione w naszym kościółku" (cyt. za A. S tró żew sk a - N a k o u zi, Dary Marii Ludwiki Gonzagi i Jana Kazimierza dla klasztoru sióstr Wizytek w Warszawie. Z dziejów królewskiego mecenatu artystycznego w XVII w., praca magisterska przygotowana pod kierunkiem K. Moisan-Jabłońskiej na Akademii Teologii Katolickiej w Warszawie, Warszawa 1995, mnps w Bibliotece Uniwersytetu Kardynała Stefana Wyszyńskiego w Warszawie, sygn. 115380, s. 16).

${ }^{26}$ Tamże, poz. kat. 25 na s. 81 . 
które najpewniej zostały wykonane w Augsburgu. Całe, tak zdobione tabernakulum, przywodzi swym charakterem na myśl krakowski wyrób tego rodzaju, powstały niedługo później, a przy tym dobrze rozpoznany od strony historycznej: tabernakulum w kaplicy Batorego w katedrze na Wawelu, wykonane przez miejscowych artystów w latach $1659-1660^{27}$. Tabernakulum wawelskie pozwala nam chociaż w części wyobrazić sobie, jak pierwotnie wyglądało cyborium w kościele św. Marcina.

Nie jesteśmy w stanie stwierdzić, jak w szczegółach przedstawiały się ołtarzowe srebra augsburskie $z$ fundacji Marii Klary Wittelsbach, wykonane około 1635 roku: lichtarze, dwa kielichy, krzyż, lampa i trybularz (kadzielnica). Chociaż nie do końca - można bowiem spróbować je przywołać oglądając zachowane w polskich zbiorach analogiczne, w większości bardzo okazałe, wyroby augsburskie z tego czasu ${ }^{28}$ : komplet pięciu (pierwotnie sześciu) świeczników ołtarzowych autorstwa Johannesa I Lenckera $z$ lat około 1624-1625, fundacji królowej Konstancji, żony Zygmunta III Wazy (Muzeum Diecezjalne w Opolu oraz zbiory Zamków Królewskich w Warszawie i na Wawelu), kielich wykonany przez Davida I Schwerstermüllera $z$ lat około 1630-1635 (Muzeum Narodowe w Warszawie), krzyż ołtarzowy Gregora Zorera z okolo 1630 roku (klasztor wizytek w Warszawie), lampa wieczna sporządzona przez Davida Rolla w latach około 1620-1630, będąca fundacją opata Kaspra Kozielskiego dla kościoła klasztomego w Wagrowcu (obecnie w kościele św. Wojciecha w Poznaniu) czy też na koniec z braku zabytków z piewrszej połowy sięgając do zasobów z drugiej połowy stulecia - kadzielnica Antoniusa Lesera $z$ lat około 1685-1690 (klasztor wizytek w Krakowie). Zestawienie powyższe, choć nie może być podstawą do rekonstrukcji sreber wykonanych z inicjatywy Marii Klary Wittelsbach, obrazuje jednak wielki rozmach tej fundacji, która została dokonana w okresie największej świetności zlotnictwa augsburskiego.

Jeszcze jedna szczegółowa kwestia wymaga poruszenia w związku $\mathrm{z}$ omawianym tu, zaginionym już w XVII wieku, zespołem sreber ołtarzowych z karmelitańskiego kościoła św. Marcina. Jak łatwo zauważyć, w zespole tym brakuje monstrancji. Można to dość latwo wyttumaczyć: w 1624 roku do kościoła sprawiona została monstrancja, której główną - choć nie jedyną - fundatorką była Agnieszka z Tęczyńskich Firlejowa, wielka opiekunka zakonu karmelitów bosych. $Z$ zapisu źródłowego jednoznacznie wynika, iż monstrancję wykonano w Poznaniu $^{29}$. Znając twórczość tamtejszego ośrodka w pierwszej połowie XVII wieku ${ }^{30}$

${ }^{27}$ J. K. C z y ż e w s k i, Konserwacja oltarza i tabernakulum w kaplicy Batorego w katedrze na Wawelu, „Studia Waweliana” t. V, 1996, s. 197-203.

${ }^{28}$ Aby nie mnożyć przypisów rezygnuję w tym miejscu z powoływania szczegółowej literatury i referowania stanu badan. Wszystkie wymienione dalej zabytki prezentowane były w 2004 roku na wystawie w Muzeum Narodowym w Krakowie, zatytułowanej Świat ze srebra. Ztotnictwo augsburskie od XVI do XIX wieku w zbiorach polskich, i omówione są wyczerpująco w katalogu wystawy (w przygotowaniu do druku). Podane dalej datowania i określenia autorstwa zabytków są zgodne z ustaleniami zawartymi w tymże katalogu.

${ }^{29}$ Zob. AKKB, rkps sygn. 38, Księga..., s. 264, pod dat ${ }^{1} 1624$ : „Monstrancję skończono w Poznaniu, na którą JMP. Agnieszka Firlejowa Wojewodzina Krak[owska] fundatorka WW. OO. Naszych na Puszczy, dała zł: 1000, dołożyły MM. z Opatrznoœci Boskiej zł: 1039, oprócz pereł i klejnotów, któremi ozdobiona jest. Kosztuje zł. 2039". 
możemy być absolutnie pewni, iż monstrancja z 1624 roku musiała posiadać typowy dla tego czasu, nieco archaiczny kształt: z częścią górną o formie przypominającej średniowieczne retabulum czy inaczej, przekrój gotyckiego kościoła. Tak się składa, iż ta sama Agnieszka z Tęczyńskich Firlejowa, zapewne tuż przed 1640 rokiem sprawiła do ufundowanego przez siebie eremu karmelitów bosych w Czernej monstrancję, powszechnie uważaną dziś za dzieło nieznanego nam złotnika augsburskiego sygnującego swe prace monogramem „,MB ${ }^{31}$. Monstrancja z Czernej prezentuje bardzo, jak na owe czasy, nowoczesne rozwiązanie z częścią górną $w$ formie promienistej glorii. Ostensorium to należy do grupy kilku wyrobów tego rodzaju, wykonanych przez nie znanego nam bliżej augsburskiego złotnika (czynnego być może w Polsce?), pracującego dla polskich klientów - do wspomnianej grupy należą: stopa i nodus monstrancji z kościoła św. Wojciecha w Krakowie, relikwiarz Gwoździa Pańskiego w katedrze na Wawelu fundacji arcybiskupa lwowskiego Stanisława Grochowskiego, monstrancje w Lasku, Połańcu (z wymienioną stopa), Piotrkowicach i - zapewne - stopa monstrancji w Ołyce. Istnieja przesłanki, by przypuszczać, iż tego rodzaju monstrancja znajdowała się także niegdyś w kościele karmelitów w Wiśniczu Nowym (w każdym razie zamówiono ją w Augsburgu) $)^{32}$.

Trudno na tym miejscu wyciagać zbyt daleko idące wnioski z tego zasobu faktów. Kontakty Polski, dworu królewskiego i Krakowa z Augsburgiem były na tyle żywe, iż nie można przeceniać znaczenia pojedynczego impulsu. Ale mogło być tak, iż wyjątkowo okazała fundacja Marii Klary Wittelsbach dla kościola św. Marcina stała się bodźcem dla Agnieszki Firlejowej i grupy bogatych polskich zleceniodawców poszukujących argentariów kościelnych stojących na najwyższym poziomie - a takie wyroby byli w stanie w ówczesnej Europie Środkowej dostarczyć właśnie złotnicy augsburscy. Przykład Albrychta Radziwiłła odwiedzającego kościół św. Marcina w Krakowie, aby podziwiać tabernakulum fundacji Marii Klary Wittelsbach, jest dowodem, że nowe dzieła sztuki były bacznie obserwowane i naśladowane. Dzieła zamówione w Augsburgu przez bawarską księżniczkę około 1635 roku mogły być istotnym impulsem dla wzrostu zainteresowania twórczością tego ośrodka zaledwie kilka lat później, około 1640 roku.

Fundacje artystyczne s. Teresy Marii od św. Józefa, karmelitanki u św. Marcina w Krakowie, są dziś niemal zupełnie zapomniane, choć - jak wiele na to wskazuje - w latach 30. XVII wieku ich pojawienie się w Krakowie było wydarzeniem o randze nie tylko religijnej, ale też artystycznej. Dziś $\mathrm{z}$ tego wydarzenia pozostał jedynie ogólnikowy spis oltarzowych sreber, odarte z ozdób tabemakulum i portret fundatorki pieczołowicie przechowywany przez karmelitanki bose w klasztorze na Wesołej w Krakowie ${ }^{33}$.

${ }^{30}$ Por. A. W a silkows ka, Z badań nad zlotnictwem wielkopolskim $w$ XVII i pocz. XVIII w. [w:] O rzemiośle artystycznym w Polsce, Warszawa 1976, s. 124 i il. na kolejnych s.

${ }^{31} \mathrm{M}$. W oźni a k, Wptywy augsburskie w ztotnictwie gdańskim XVII $i$ XVIII wieku, „Biuletyn Historii Sztuki”, R. XLVII, 1985, nr 1-2, s. 114-115.

${ }^{32}$ Zob. Wawel 1000-2000. Wystawa Jubileuszowa, t. II: Skarby Archidiecezji Krakowskiej. Muzeum Archidiecezjalne w Krakowie, maj-wrzesień 2000. Katalog, Kraków 2000, gdzie omówiona dokładnie monstrancja z Czernej i zrelacjonowany krytycznie stan badań odnośnie całej grupy - poz. kat. II/156 na s. 179-180 (notę katalogową oprac. J. Żmudziński).

${ }^{33}$ Portret ten, przedstwiający starszą kobietę ubraną w habit karmelitański, o dobrodusznym obliczu, namalowany jest olejno na płótnie $(45 \times 33 \mathrm{~cm}$; w ramie $55 \times 42 \mathrm{~cm})$; na odwrocie 
Aneks. Opis tabernakulum na ołtarzu głównym w kościele klasztornym karmelitanek bosych pw. św. Marcina w Krakowie (Archiwum Klasztoru Karmelitanek Bosych na Wesołej w Krakowie, rkps sygn. 33, dokument luźny: Regestr srebra kościola S. Marcina, bez daty [przed 1787 r.], jedna karta nlb. $)^{34}$

Cymborium cate hebanowe. Na kopule tego cymborium jest aniotków dwa dużch catych srebrnych, skrzydet trzy; otwarte za kotem imie Jezus srebrne, w koto promienie; za kotem jest sztuczka srebrna; pod spodem jest obraz P[ana] N[aszego] J[ezusa] w sukienkach; jest sztuczek koto obrazka srebrnych 4, inszych sztuczek srebrnych catych 22, [...] sztuczka kawateczka nie ma, jest sztuk srebrnych 3, jedna cata bez matego kawatka, jest za kolem w pierwszej sztuce 7 [?] kawatków, w drugiej 4 srebrnych, 2 cynowe, w trzeci[ej] sztuczek srebrnych 6, siódma cynowa. Drut caly srebrny do zawieszania firanek, drut w groszek, którym cymboritum jest obwiedzione, nie dostaje trzech malych kawatków. Ponizzej jest aniolków matych srebrnych 6 w calości, siódmy cynowy. Między temi aniotkami jest esików srebrnych 6. Drut srebrny wkolo okienek jest w calości w groszek. Aniolków 8 ze skrzydelkami calych srebrnych we dwóch okienkach, w trzecim okienku aniolków 3, aniolków w środku 2 nad okienkiem, aniolków malutkich 4. Esów srebrnych 2, między temi sztukami jest aniotków 2. Niżej kopuly, między odcinkami, sztuczek srebrnych większych 8, dwie sztuczki poutamywane, których jest po potowie. Pod temi gatkami jest sztuczek srebrnych catych 8. Na stupkach kapiteli srebrnych 8, dwie cynowe, między temi kapitelami drutu w groszek srebrnego kawalków 6. Blaszek wkoto tego drutu srebrnych wycinanych 6. Aniolków srebrnych 2, jeden bez skrzydetka, pod stupkami wazoników srebrnych 10. Drutu na gzemsiku kawatków 18, nad stupkami druciku kawatków I0 [?]. W środku [w] gzemsie sztuczek floresowych 3. Drzwi ze cymborium srebrne, krucyfiks jest odliwany, za krucyfiksem jest blacha srebrna wyzłacana. Na gtowie P[ana] J[ezusa] korona wyzlacana. Osób srebrnych dwie N[ajświętszej] P[anny] i S[więtego] Jana. Nad gtowanti tych osób cyrkutów srebrnych 2 pozlacanych. Trupia glówka srebrna z blacha srebrnq i kosteczki dwie cate posrebrzane. Blacha, postument pod osobami srebrny, nad gtowa P[ana] J[ezusa] kartelusz srebrny. Drut wokoto przewieszek srebrny w groszek, nie dostaje kawatka. U tych zer[wanych?] przewieszek, aniołków srebrnych 4 odliwanych, nad teni drzwiczkami różyczek srebrnych 2. Aniolków srebrnych 2, sztuczek przy drzwiczkach srebrnych 4. Pod stupkami sztuczek srebrnych floresy 8. Osób dwie dużych srebrnych z koronami srebrnymi wyzlacanemi, przy nogach jednej osóbki srebrnego polowy palca jednego nie masz. Na spodzie pod cymborium sq drzwiczki, na których jest blacha srebrna. Kolo tych drzwiczek do polowy drut srebrny. Obrazków srebrnych 4. Obrazków w ramkach srebrnych 4. Nad obrazkami sztuczek srebrnych 8. Miejscami powylamywane znacznie $[\ldots]$.

opatrzony jest dwoma napisami: na płótnie - W. M. Teresa Marya - Klara od s. oO. N. Józefa $\mid$ Na świecie Klara infantka $\mid$ księżniczka Bawarska $\mid$ Ur. [tu zostawione puste miejsce] + 16[2?]0 | Jej głowa spoczywa w Karmelu na Wesolej.; na ramie: u góry - Matka Teresa Maria + $1620 \mathrm{r}$ | z domu Księżniczka Klara Bawarska | : piszacy prosi za nim do Boga |Kraków | w Maju 1902 roku; po prawej - Ten portrecik byt bardzzo zniszczony $i$ odrestaurowat go artysta malarz w 1902 roku|W. P. Gorzkowski. NIe ma powodów, by podważać wiarygodność tradycji potwierdzonej przez te napisy, z których pierwszy mogł powstać najwcześniej po kasacie klasztoru przy kościele św. Marcina w 1787 roku, wspomniano w nim bowiem przeniesienie czaszki portretowanej na Wesołą. Malarza Gorzkowskiego, który odnawiał obraz w 1902 roku nie wymienia Stownik artystów polskich.

${ }^{34} \mathrm{~W}$ tekst, partiami w zasadzie zupełnie pozbawiony przecinków, wstawiono znaki interpunkcyjne niezbędne dla zrozumienia opisu - w wielu wypadkach nadal jednak pozostają wątpliwości, co do prawidłowego zrozumienia przekazu. 


\section{Art Findings of Bavarian Princess Maria Klara Wittelsbach, in Convent Called Teresa Maria od św. Józefa (1608-1652), a Discalced Carmelite Nun in St. Martin's Convent Summary}

Maria Klara Wittelsbach (1608-1652) was a daughter of Ferdinand (brother of Wilhelm $\mathrm{V}$, who ruled in Munich) and Mary. Through her sister she was closely related to the Hapsburgs and Vasas, who ruled in Poland. Beginning with 1618 Maria Clara was brought up at the king's court in Warsaw. In 1634 she joined the Carmelite order at St. Martin's church in Cracow and took a name Teresa Maria od św. Józefa. In 1649 she was chosen prioress of the convent and in 1652 she died in a plague. On joining the convent the Bavarian princess devoted considerable sums to have a new church built and procure a silver altar set (six altar candlesticks, two chalices, a crucifix, a lamp, a censer), which she ordered in Augsburg, as well as a wooden tabernacle, adorned with silver (the decoration may have been made in Augsburg, too). The altar set was looted by the Swedes during the war 1655-1657. The tabernacle stood on the main altar of St. Martin's church until 1787, and after the dissolution of the convent it was moved to another church of the same congregation in Cracow (in Kopernika Street). In 1793 the silver decorations from the tabernacle were sold and replaced by a new, much simpler decoration. The tabernacle has been preserved to our times and in its design one can easily trace imitation of a design by an Italian architect Giovanni Battista Montano (1534-1621), released in 1628. No details are known about the silver altar set. There are grounds to infer that the procurement from Augsburg ca 1635 of a sumptuous silver set for religious purposes and its shipment to Cracow helped develop contacts between Cracow's and Augsburg's goldsmiths. 


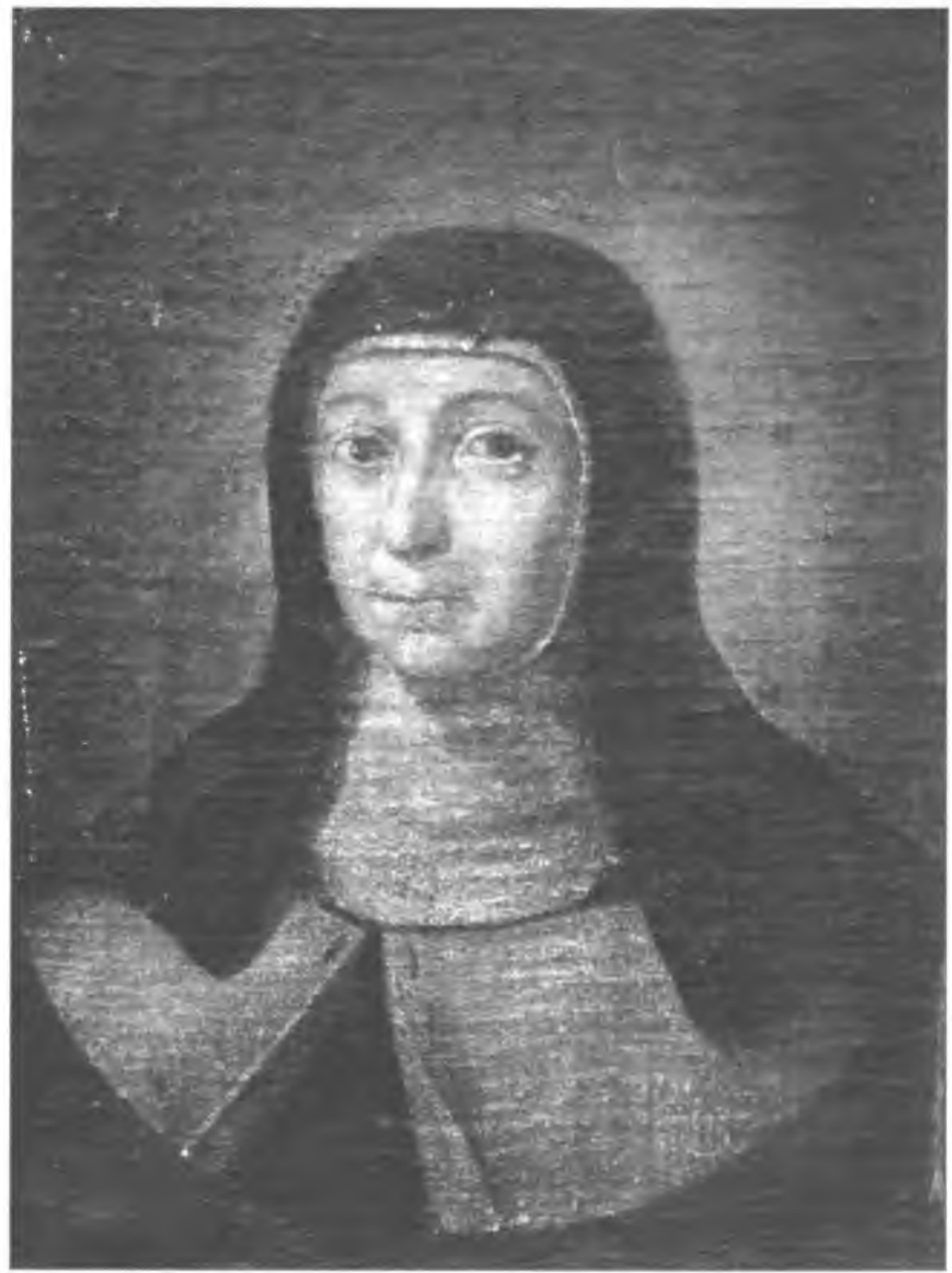

1. Malarz nieznany. Portret Marii Klary Wittelsbach, w zakonie siostry Teresy Marii od św. Józefa (1608-1652), karmelitanki bosej. 2 połowa XVII w. Kraków, klasztor karmelitanek bosych na Wesołej. Fot. Janusz Kozina. 


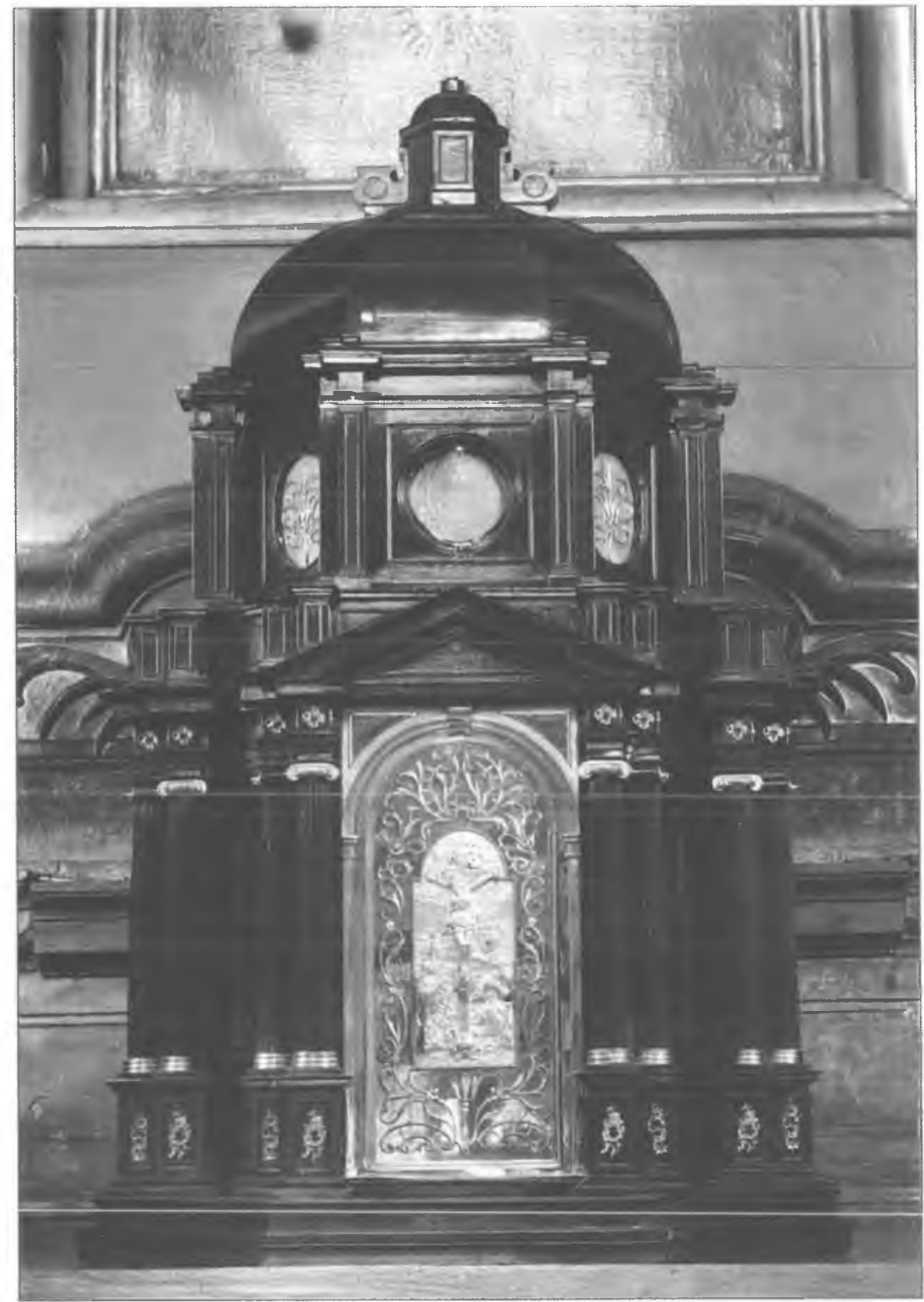

2. Tabernakulum. Około 1635 r., z aplikacjami metalowymi z około 1793 r. Kraków, kościół klasztorny karmelitanek bosych na Wesołej, ołtarz główny. Fot. Janusz Kozina. 